\title{
AKTIVITAS ANTIBAKTERI EKSTRAK ETANOL BIJI KAPULAGA JAWA (Amomum compactum Soland. ex Maton) TERHADAP Streptococcus pyogenes
}

\author{
Oom Komala ${ }^{1 *}$, Ismanto ${ }^{1}$, Muhammad Alan Maulana ${ }^{1}$ \\ ${ }^{1}$ Program Studi Biologi, FMIPA, Universitas Pakuan, Bogor. \\ *e-mail: oom.komala@ unpak.ac.id
}

diterima: 8 Januari 2020; direvisi: 11 Februari 2020; disetujui: 2 Maret 2020

\begin{abstract}
ABSTRAK
Streptococcus pyogenes merupakan salah satu bakteri patogen penyebab penyakit faringitis. Pengobatan alami untuk mengatasi penyakit tersebut dengan menggunakan biji kapulaga. Tujuan penelitian ini adalah menguji aktivitas antibakteri, menentukan konsentrasi daerah hambat dan senyawa fitokimia dari ekstrak etanol 96\% biji kapulaga jawa (Amomum compactum Soland. ex Maton) terhadap Streptococcus pyogenes. Metode yang digunakan adalah metode dilusi padat dan metode difusi kertas cakram. Metode dilusi padat digunakan untuk uji Konsentrasi Hambat Minimum (KHM) dengan konsentrasi 1,25\%, 2,5\%, 5\% dan 7,5\% sedangkan metode difusi kertas cakram digunakan untuk uji Diameter Daerah Hambat (DDH) dengan menggunakan lima macam perlakuan yaitu tiga konsentrasi ekstrak etanol 96\% biji kapulaga jawa $(7,5 \%, 10 \%$ dan $12 \%)$, satu kontrol positif amoksisilin $0,01 \mathrm{mg} / \mathrm{mL}$ dan satu kontrol negatif akuades steril. Data hasil uji DDH kemudian di analisis menggunakan Anova dengan tingkat kepercayaan $95 \%$ dan $\alpha=0,05$ serta uji lanjut Duncan untuk mengetahui perbedaan antar perlakuan. Hasil penelitian menunjukan pada pengujian KHM terdapat pada konsentrasi 7,5\% sedangkan untuk uji DDH yang memiliki aktivitas tertinggi terdapat pada konsentrasi $12 \%$ dengan rata-rata diameter daerah hambat 12,03 $\pm 0,14 \mathrm{~mm}$. Selain itu, ekstrak etanol $96 \%$ biji kapulaga jawa mengandung senyawa alkaloid, flavonoid, terpenoid serta tanin yang berfungsi dalam aktivitas antibakteri.
\end{abstract}

Kata Kunci: Amomum compactum, Faringitis, Streptococcus pyogenes

\section{ANTIBACTERIAL ACTIVITY OF JAVA CARDAMOM SEED EXTRACT (Amomum compactum Soland. ex Maton) AGAINST Streptococcus pyogenes}

\begin{abstract}
Streptococcus pyogenes is one of the pathogenic bacteria that causes pharyngitis. Natural treatment to overcome these problems is to use cardamom seeds. The purpose of this study was to test the antibacterial activity, determine the concentration of inhibitory zone and phytochemical compounds from ethanol 96\% extract of Java cardamom seeds (Amomum compactum Soland. Ex Maton) against Streptococcus pyogenes. The method is used solid dilution and paper disc diffusion method. The solid dilution method is used for the Minimum Inhibitory Concentration (MIC) test with a concentration of $1.25 \%, 2.5 \%, 5 \%$ and $7.5 \%$ while the paper diffusion method is used for the Inhibition zone Diameter (IZD) using five treatments namely three concentrations of ethanol $96 \%$ extract of Java cardamom seeds (7.5\%, $10 \%$ and $12 \%$ ), one positive control of amoxicillin $0.01 \mathrm{mg} / \mathrm{mL}$ and one negative control of sterile distilled water. IZD data were analyzed using ANOVA with a confidence level of $95 \%$ and $\alpha=$ 0.05 and Duncan's further tests to determine differences between treatments. The results showed that the MIC was at a concentration of $7.5 \%$ while for the IZD test which had the highest activity there was a concentration of $12 \%$ with an average inhibition diameter of $12.03 \pm 0.14$ $\mathrm{mm}$. In addition, ethanol $96 \%$ extract of Java cardamom seeds contain alkaloids, flavonoids, terpenoids and tannins which function in antibacterial activity.
\end{abstract}

Key words: Amomum compactum. Pharyngitis, Streptococcus pyogenes 
PENDAHULUAN

Streptococcus $\beta$ hemolyticus Grup A atau Streptococcus pyogenes merupakan salah satu bakteri patogen yang banyak menginfeksi manusia. Bakteri ini merupakan bakteri penyebab paling umum dari faringitis akut, dimana prevalensi kasus pada anak-anak sekitar 20 - 30\% dan pada orang dewasa sekitar 5 - 15\% (Aini dkk., 2016; Shulman et al., 2012). Di Indonesia kasus faringitis akut pada tahun 2004 termasuk ke dalam sepuluh penyakit terbanyak pada pasien rawat jalan dengan persentase jumlah penderita sebesar $1,5 \%$ atau sebanyak 214.781 orang (Depkes RI, 2006).

Faringitis yang disebabkan oleh bakteri memiliki gejala berupa sakit kepala hebat, muntah, kadang demam dengan suhu yang tinggi dan jarang disertai batuk (Kemenkes RI, 2013). Pengobatan faringitis umumnya menggunakan sejumlah antibiotik, akan tetapi pengobatan dengan antibiotik dapat menimbulkan efek samping seperti reaksi alergi, reaksi idiosinkrasi, reaksi toksik serta terjadinya perubahan biologik dan metabolik (Indijah dan Fajri, 2016).

Kapulaga merupakan salah satu tanaman yang termasuk dari suku Zingiberaceae dan bermanfaat sebagai bumbu masakan maupun obat-obatan. Di Indonesia tanaman kapulaga memiliki dua macam jenis yaitu kapulaga sabrang (Elettaria cardamomum (L.) Maton) dan kapulaga jawa (Amomum compactum Soland. ex Maton) (Setyawan et al., 2014).

Menurut Agoes (2010) biji kapulaga diketahui memiliki berbagai macam khasiat seperti mengencerkan dahak, memudahkan pengeluaran air dari perut, menghangatkan, membersihkan darah, menghilangkan rasa sakit, stimulan dan pemberi aroma. Menurut Lee et al., (2010), ekstrak A. compactum memiliki nilai potensi terapi bila digunakan sebagai ajuvan untuk pengobatan imunomodulator alergi asma. Sehubungan dengan hal itu, senyawa yang terkandung di dalam biji kapulaga seperti fenol, tanin dan terpenoid mampu menghambat aktivitas pertumbuhan bakteri pada Escherichia coli dan Staphylococcus aureus (Sukandar dkk., 2015). Dari hasil tersebut perlu dilakukannya sebuah penelitian dari ekstrak pelarut etanol $96 \%$ biji kapulaga jawa (Amomum compactum Soland. ex Maton) untuk mengetahui adanya aktivitas antibakteri pada Streptococcus pyogenes.

Tujuan dari penelitian ini adalah untuk menguji aktivitas antibakteri, menentukan konsentrasi daerah hambat dan menentukan senyawa fitokimia dari ekstrak etanol $96 \%$ biji kapulaga jawa terhadap pertumbuhan Streptococcus pyogenes.

\section{BAHAN DAN METODE}

\section{Determinasi Tanaman Kapulaga Jawa}

Determinasi tanaman kapulaga jawa dilakukan di Pusat Penelitian Konservasi Tumbuhan dan Kebun Raya-LIPI Bogor, Jalan Ir. H. Juanda No. 13 Bogor, Provinsi Jawa Barat.

\section{Preparasi Sampel Biji Kapulaga Jawa}

Sampel sebanyak $10 \mathrm{~kg}$ didapatkan dari petani yang bertempat di Desa Cileungsi, Kecamatan Ciawi, Kabupaten Bogor. Buah kapulaga dicuci di bawah air mengalir dan dikeringkan di bawah sinar matahari langsung selama tujuh hari. Buah selanjutnya disortasi dan diambil bijinya. Biji diblender dan diayak dengan menggunakan saringan mesh. Hasil saringan mesh akan didapatkan simplisia serbuk biji kapulaga jawa.

\section{Uji Kadar Air Simplisia Serbuk Biji Kapulaga Jawa}

Pertama-tama cawan dikeringkan pada suhu $105^{\circ} \mathrm{C} \pm 30$ menit. Setelah itu, cawan diletakkan dalam desikator dan sampel 
ditimbang sebanyak 5 g. Sampel dimasukkan ke dalam oven dengan suhu $105^{\circ} \mathrm{C}$ selama \pm 6 jam. Setelah itu, dimasukkan ke dalam desikator kembali kemudian ditimbang hingga memperoleh bobot konstan.

\section{Pembuatan Ekstrak Etanol 96\% Biji Kapulaga Jawa}

Simplisia sebanyak 200 g diekstraksi dan dimaserasi menggunakan pelarut etanol 96\% sebanyak $2000 \mathrm{~mL}$ selama $3 \times 24$ jam. Proses dilakukan secara bertingkat dengan menuangkan pelarut sebanyak $700 \mathrm{~mL}, 700$ $\mathrm{mL}$ dan $600 \mathrm{~mL}$ Maserat didiamkan selama 1 x 24 jam dengan sesekali diaduk dan disimpan pada suhu ruang. Maserat disaring dengan kertas saring sehingga akan didapatkan filtrat dan residu. Semua filtrat dievaporasi dengan rotary evaporator pada suhu $50^{\circ} \mathrm{C}$.

\section{Uji Kadar Abu Ekstrak Etanol 96\% Biji Kapulaga Jawa}

Ekstrak sebanyak 2 gram di masukkan ke dalam cawan porselen yang sebelumnya sudah ditimbang. Ekstrak dipijar menggunakan tanur dengan suhu $600^{\circ} \mathrm{C}$ hingga mendapatkan bobot konstan dan ditimbang hingga bobotnya tetap.

\section{Uji Fitokimia Ekstrak Etanol 96\% Biji} Kapulaga Jawa

\section{Uji Alkaloid}

Satu gram ekstrak ditetesi $\mathrm{HCl} 2 \mathrm{~N}$, lalu dibagi dalam beberapa tabung reaksi. Setiap tabung ditambahkan dengan masingmasing pereaksi. Pereaksi Mayer positif mengandung alkaloid jika membentuk endapan putih atau kuning. Pereaksi Wagner positif mengandung alkaloid jika terbentuk endapan coklat. Pereaksi Dragendrof, positif mengandung alkaloid jika terbentuk endapan jingga.

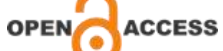

\section{Uji Flavonoid}

Satu gram ekstrak dilarutkan dengan 1 $\mathrm{mL}$ etanol $96 \%$, lalu ditambahkan serbuk magnesium, kemudian ditambahkan HCL pekat. Apabila terbentuk warna oranye, merah atau kuning, berarti positif flavonoid.

\section{Uji Saponin}

Satu gram ekstrak ditambahkan $5 \mathrm{~mL}$ air panas, didinginkan lalu kocok kuat-kuat selama 10 detik. Apabila terbentuk busa setinggi $1-10 \mathrm{~cm}$ selama tidak kurang dari 10 menit dan pada penambahan 1 tetes $\mathrm{HCl}$ $2 \mathrm{~N}$ busa tidak hilang maka positif saponin.

\section{Uji Steroid dan Terpenoid}

Satu gram ekstrak ditambahkan $3 \mathrm{~mL}$ eter kemudian dikocok. Lapisan eter diambil lalu ditambahkan 2-3 tetes pereaksi Liebermen Bouchard. Apabila terbentuk warna merah keunguan, berarti positif terpenoid tetapi apabila terbentuk warna hijau berarti positif steroid.

\section{Uji Tanin}

Satu gram ekstrak ditambahkan $5 \mathrm{~mL}$ akuades dan dipanaskan selama 5 menit, dikocok hingga homogen lalu disaring. Filtrat hasil saringan ditambahkan $\mathrm{FeCl}_{3} 3 \%$ sebanyak 2 tetes, jika menghasilkan warna hitam kehijauan atau hijau violet maka positif senyawa tanin.

\section{Pembuatan Kertas Cakram}

Kertas saring dengan diameter $6 \mathrm{~mm}$ disterilisasi di dalam oven selama 1 x 24 jam dengan suhu $105^{\circ} \mathrm{C}$. Kertas saring ditetesi dan direndam pada konsentrasi ekstrak 7,5\%, 10\% dan 12\%, serta larutan antibiotik amoksisilin $0,01 \mathrm{mg} / \mathrm{mL}$ sebagai kontrol positif dan akuades steril sebagai kontrol negatif. Hasil perendaman kemudian dimasukkan ke dalam oven dengan suhu $40^{\circ} \mathrm{C}$ selama 1 x 24 jam. 
Pembuatan Media Brain Heart Infusion Agar (BHI Agar)

Serbuk BHI ditimbang sebanyak $37 \mathrm{~g}$ dan ditambah $15 \mathrm{~g}$ bacto agar kemudain dilarutkan dalam $1000 \mathrm{~mL}$ akuades. Media agar dimasukkan ke dalam autoklaf dengan suhu $121^{\circ} \mathrm{C}$ dengan tekanan 1 atm selama 15-20 menit.

\section{Peremajaan Bakteri Streptococcus pyogenes}

Bakteri didapatkan dari Departemen Mikrobiologi, Fakultas Kedokteran, Universitas Indonesia. Peremajaan dilakukan dengan mengambil sediaan satu ose biakan murni kemudian diinokulasikan pada media BHI Agar miring. Hasil inokulasi kemudian di inkubasi di dalam inkubator selama 1 x 24 jam.

\section{Pengujian Aktivitas Antibakteri Ekstrak Etanol 96\% Biji Kapulaga Jawa}

Sebelum dilakukan pengujian bakteri hasil peremajaan kemudian dilakukan pengenceran dengan $\mathrm{NaCl}$ fisiologis $0,9 \%$. Pengenceran dilakukan sampai konsentrasi $10^{-6} \mathrm{koloni} / \mathrm{mL}$ dengan mengikuti prosedur pengenceran standar McFarland 0,5.

\section{Uji Konsentrasi Hambat Minimum (KHM)}

Sebanyak $15 \mathrm{~mL}$ BHI Agar dimasukkan ke dalam cawan petri dan ditambahkan 0,2 mL suspensi bakteri serta bahan uji sebanyak $1 \mathrm{~mL}$. Campuran dihomogenkan dan didiamkan hingga media agar padat, lalu dimasukkan ke dalam inkubator selama 1 x 24 jam dengan suhu $37^{\circ} \mathrm{C}$.

\section{Uji Diameter Daerah Hambat (DDH)}

Cawan petri diisi media BHI Agar sebanyak $15 \mathrm{~mL}$ dan ditetesi suspensi bakteri sebanyak 0,2 $\mathrm{mL}$ secara zig-zag lalu didiamkan hingga agar padat. Kemudian 5 jenis kertas cakram diletakkan yaitu: 1 kontrol negatif, 1 kontrol positif, dan 3 konsentrasi ekstrak 7,5\%,10\% dan 12\% lalu disimpan di inkubator dengan suhu $37^{\circ} \mathrm{C}$ selama 1 x 24 jam.

\section{Parameter yang Diamati}

Mengukur diameter daerah hambat dari ekstrak etanol $96 \%$ biji kapulaga jawa terhadap bakteri Streptococcus pyogenes serta menentukan golongan senyawa bioaktif dari ekstrak etanol $96 \%$ biji kapulaga jawa.

\section{Analisis Data}

Rancangan yang digunakan adalah Rancangan Acak Lengkap (RAL). Analisis data menggunakan Analysis of Variance (Anova) satu arah dengan tingkat kepercayaan $95 \%$ dan $\alpha=0,05$ serta uji lanjut Duncan untuk mengetahui perbedaan antar perlakuan.

\section{HASIL DAN PEMBAHASAN}

\section{Determinasi Tanaman Kapulaga Jawa}

Determinasi tanaman dilakukan untuk memastikan kebenaran dan kejelasan suatu tanaman yang akan digunakan pada saat proses penelitian dan bertujuan untuk menghindari adanya kesalahan dalam pemilihan suatu sampel bahan. Determinasi tanaman dilakukan di Pusat Penelitian Konservasi Tumbuhan dan Kebun RayaLIPI Bogor dengan sampel yang dibawa yaitu berupa tanaman yang meliputi akar, batang, daun, dan buah. Hasil determinasi menunjukkan bahwa tanaman yang dideterminasi adalah jenis kapulaga jawa (Amomum compactum Sol. ex Maton) dari suku Zingiberaceae. 


\section{Kadar Air Simplisia Serbuk Biji Kapulaga Jawa}

Kadar air merupakan banyaknya air yang dinyatakan dalam persentase massa (SNI, 1992). Hasil pengujian kadar air menyatakan bahwa simplisia serbuk biji kapulaga jawa memiliki rata-rata kadar air sebesar $11,73 \pm 0,04 \%$, hasil tersebut sudah sesui dengan persyaratan mutu kapulaga lokal berdasarkan SNI-01-3180-1992 yaitu maksimal $12 \%$.

\section{Ekstrak Etanol 96\% Biji Kapulaga Jawa}

Serbuk sebanyak 600 gram yang telah dimaserasi dan dirotari evaporasi menghasilkan ekstrak kental sebanyak 17,4 gram dengan rendemen sebesar 2,9\%. Ekstrak yang didapat dari proses rotari evaporasi memiliki warna coklat kuning kemerah-merahan. Pelarut yang digunakan dalam proses ekstraksi adalah pelarut etanol 96\%, hal ini dikarenakan menurut Arifianti dkk. (2014) pelarut etanol beserta campurannya dengan air mempunyai extractive power yang terbaik untuk hampir semua senyawa yang mempunyai berat molekul rendah. Hasil pengamatan ekstrak etanol $96 \%$ biji kapulaga jawa dapat dilihat pada Tabel 1.

Hasil pengujian kadar abu didapatkan bahwa ekstrak etanol 96\% biji kapulaga jawa memiliki kadar abu sebesar $12,14 \pm 0,03 \%$. Pengujian kadar abu dilakukan karena bertujuan untuk menentukan baik atau tidaknya suatu pengolahan maupun mengetahui jenis bahan yang digunakan (Pine dkk., 2015).

Tabel 1. Hasil Karakteristik Ekstrak Etanol 96\% Biji Kapulaga Jawa

\begin{tabular}{ccccccc}
\hline Bahan Uji & $\begin{array}{c}\text { Warna } \\
\text { Filtrat }\end{array}$ & $\begin{array}{c}\text { Warna } \\
\text { Ekstrak }\end{array}$ & $\begin{array}{c}\text { Bobot } \\
\text { Awal }\end{array}$ & $\begin{array}{c}\text { Bobot } \\
\text { Ekstrak }\end{array}$ & Rendemen & Kadar Abu \\
\hline $\begin{array}{c}\text { Ekstrak Etanol } \\
96 \% \text { Biji }\end{array}$ & $\begin{array}{c}\text { Kuning } \\
\text { Kapulaga }\end{array}$ & $\begin{array}{c}\text { Coklat } \\
\text { Kuning }\end{array}$ & $600 \mathrm{~g}$ & $17,4 \mathrm{~g}$ & $2,9 \%$ & $12,14 \pm 0,03 \%$ \\
Jawa & & $\begin{array}{c}\text { Kemerah- } \\
\text { merahan }\end{array}$ & & & & \\
\hline
\end{tabular}

\section{Kandungan Fitokimia Ekstrak Etanol 96\% Biji Kapulaga Jawa}

Berdasarkan hasil pengujian fitokimia pada Tabel 2 dapat dinyatakan bahwa ekstrak etanol $96 \%$ biji kapulaga jawa memiliki kandungan senyawa alkoloid, flavonoid, terpenoid dan tanin. Hasil tersebut sedikit berbeda dengan hasil penelitian Sukandar dkk. (2015) pada ekstrak metanol biji kapulaga (Amomum compactum Sol. ex Maton) yang memiliki senyawa fenol, tanin dan terpenoid (Tabel 2).
Tabel 2. Hasil Uji Fitokimia Ekstrak Etanol 96\% Biji Kapulaga Jawa

\begin{tabular}{cc}
\hline Uji Senyawa & Hasil Pengujian \\
\hline Alkaloid & + \\
Flavonoid & + \\
Saponin & - \\
Steroid & - \\
Terpenoid & + \\
Tanin & + \\
\hline $\begin{array}{l}\text { Keterangan : (+) Ada Senyawa Fitokimia; (-) Tidak } \\
\text { Ada Senyawa Fitokimia }\end{array}$
\end{tabular}


Aktivitas Antibakteri Ekstrak Etanol 96\% Biji Kapulaga Jawa

\section{Konsentrasi Hambat Minimum (KHM)}

Pengujian konsentrasi hambat

minimum dilakukan untuk mengetahui konsentrasi hambatan terkecil yang ditandai dengan tidak adanya aktivitas pertumbuhan bakteri. Pengujian ini dilakukan dengan cara dilusi padat. Konsentrasi yang dibuat yaitu $1,25 \%, 2,5 \%, 5 \%$, dan 7,5\%.

Dari hasil pengujian dinyatakan bahwa konsentrasi hambat minimum pada ekstrak etanol $96 \%$ biji kapulaga jawa terdapat pada konsentrasi 7,5\%. Hasil tersebut sedikit berbeda dengan hasil penelitian Putri dkk. (2016) dengan menggunakan ekstrak etil asetat biji kapulaga (Amomum compactum) terhadap bakteri Aeromonas hydrophila yang memiliki nilai KHM sebesar 1,35\%. Perbedaan hasil KHM ini diakibatkan karena perbedaan penggunaan bahan uji dan metode pada masing-masing penelitian.

\section{Diameter Daerah Hambat (DDH)}

Pengujian diameter daerah hambat dilakukan dari tingkat konsentrasi yang telah didapatkan pada pengujian konsentrasi hambat minimum. Pengujian ini dilakukan dengan menggunakan metode Kirby-Bauer Disk Method atau difusi kertas cakram dan dilakukan sebanyak empat kali ulangan. Pengujian dilakukan dari konsentrasi 7,5\%, $10 \%$ dan $12 \%$ untuk ekstrak etanol $96 \%$ biji kapulaga jawa sedangkan untuk kontrol negatif dan kontrol positif bahan yang digunakan adalah akuades steril dan amoksisilin $0,01 \mathrm{mg} / \mathrm{mL}$. Uji diameter daerah hambat ditandai dari adanya daerah bening dari ekstrak etanol $96 \%$ biji kapulaga jawa terhadap Streptococcus pyogenes. Hasil pengujian dapat dilihat pada Gambar 1.
Hasil penelitian menunjukkan bahwa konsentrasi $7,5 \%$ memiliki nilai rata-rata diameter daerah hambat yaitu sebesar 9,15 $\pm 0,07 \mathrm{~mm}$, sedangkan konsentrasi $10 \%$ dan konsentrasi $12 \%$ memiliki nilai rata-rata diameter daerah hambat yaitu sebesar $10,90 \pm 0,20 \mathrm{~mm}$ dan $12,03 \pm 0,14 \mathrm{~mm}$. Dari hasil tersebut bila dilihat berdasarkan kategori penentuan respon hambatan menurut Greenwood (1995) pada Tabel 3 konsentrasi $7,5 \%$ termasuk ke dalam kategori tidak ada, sedangkan untuk konsentrasi $10 \%$ dan $12 \%$ termasuk ke dalam kategori lemah.

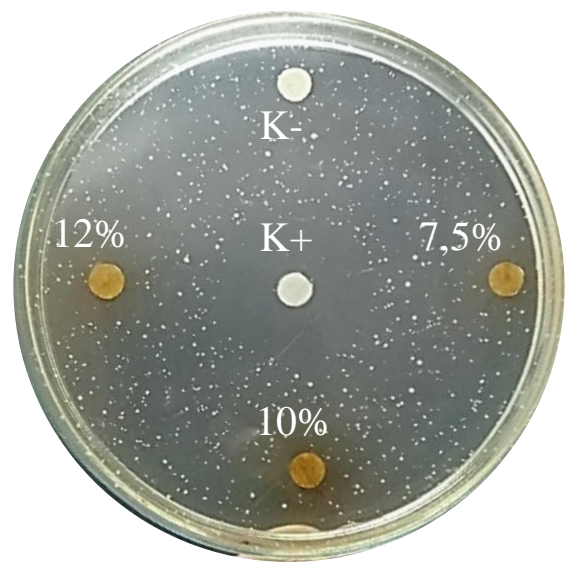

Keterangan :

$\mathrm{K}-$ = Akuades Steril;

$\mathrm{K}+=$ Amoksisilin $0,01 \mathrm{mg} / \mathrm{mL}$.

Gambar 1. Hasil Pengujian Diameter Daerah Hambat (DDH) dari Ekstrak Etanol 96\% Biji Kapulaga Jawa terhadap Pertumbuhan Streptococcus Pyogenes.

Hasil tersebut sangat berbeda jauh dengan kontrol positif dimana kontrol positif memiliki nilai rata-rata sebesar 24,06 $\pm 1,77 \mathrm{~mm}$ dengan kategori respon hambatan yaitu kuat, sedangkan untuk kontrol negatif dengan diamter $6,00 \pm 0,00$ $\mathrm{mm}$ tidak terdapat adanya respon hambatan. Besaran diameter pada kontrol negatif merupakan diameter dari kertas cakram pada pengujian diameter daerah hambat. 
Adapun hasil dari rata-rata diameter daerah hambat dapat dilihat pada Tabel 4. Berdasarkan hasil analisis data menggunakan Anova dan uji lanjut Duncan dengan tingkat kepercayaan 95\%, ekstrak etanol $96 \%$ biji kapulaga jawa diperoleh hasil signifikan sebesar 0,063 pada konsentrasi $10 \%$ dan konsentrasi $12 \%$ dengan nilai $\alpha$ sebesar 0,05 . Hasil tersebut membuktikan bahwa kedua konsentrasi

Tabel 3. Penentuan Kategori Respon Hambatan

\begin{tabular}{cc}
\hline $\begin{array}{c}\text { Diameter Daerah } \\
\text { Hambat }(\mathbf{m m})\end{array}$ & Kategori \\
\hline$\leq 10(\mathrm{~mm})$ & Tidak Ada \\
$11-15(\mathrm{~mm})$ & Lemah \\
$16-20(\mathrm{~mm})$ & Sedang \\
$\geq 20(\mathrm{~mm})$ & Kuat \\
\hline Sumber : Greenwood (1995) dalam Milah \\
dkk., (2016).
\end{tabular}

Tabel 4. Rata-Rata Diameter Daerah Hambat (DDH) Ekstrak Etanol 96\% Biji Kapulaga Jawa terhadap Streptococcus pyogenes

\begin{tabular}{ccc}
\hline $\begin{array}{c}\text { Bahan } \\
\text { Uji }\end{array}$ & $\begin{array}{c}\text { Rata-Rata DDH } \\
(\mathbf{m m})\end{array}$ & $\begin{array}{c}\text { Kategori } \\
\text { Respon } \\
\text { Hambatan }\end{array}$ \\
\hline $\mathrm{K}-$ & $6,00 \pm 0,00^{\mathrm{a}}$ & - \\
$7,5 \%$ & $9,15 \pm 0,07^{\mathrm{b}}$ & Tidak Ada \\
$10 \%$ & $10,90 \pm 0,20^{\mathrm{c}}$ & Lemah \\
$12 \%$ & $12,03 \pm 0,14^{\mathrm{c}}$ & Lemah \\
$\mathrm{K}+$ & $24,06 \pm 1,77^{\mathrm{d}}$ & Kuat \\
\hline
\end{tabular}

Keterangan :

K- = Akuades Steril;

$\mathrm{K}+=$ Amoksisilin $0,01 \mathrm{mg} / \mathrm{mL}$.

Sedangkan konsentrasi 7,5\% dan kontrol negartif memiliki pengaruh yang tidak beda nyata terhadap pertumbuhan bakteri. Hasil yang berbeda ditunjukkan pada kontrol positif yang menggunakan amoksisilin $0,01 \mathrm{mg} / \mathrm{mL}$, hasil menyatakan bahwa kontrol positif memiliki pengaruh yang sangat nyata terhadap pertumbuhan bakteri Streptococcus pyogenes.

Aktivitas adanya daerah hambat disebabkan karena adanya senyawa fitokimia yang terkandung dalam ekstrak etanol $96 \%$ biji kapulaga jawa seperti senyawa alkoloid, flavonoid, terpenoid dan tanin. Senyawa alkaloid diketahui dapat mengganggu bakteri dengan cara meracuni protoplasma, merusak dan menembus dinding sel serta mengendapkan protein. Selain itu juga, senyawa alkaloid mampu menginaktifkan enzim esensial di dalam sel mikroba meskipun pada konsentrasi yang sangat rendah serta mampu memutuskan ikatan peptidoglikan saat menerobos dinding sel. Setelah menerobos dinding sel, senyawa akan menyebabkan kebocoran isi sel dengan cara merusak ikatan hidrofobik yang berakibat pada meningkatnya permeabilitas membran. Akibat dari adanya kerusakan pada membran sel maka akan menyebabkan terhambatnya aktivitas dan biosintesis enzim-enzim spesifik yang diperlukan dalam reaksi metabolisme sehingga pertumbuhan bakteri dapat dihambat (Robinson, 1991 dalam Putri dkk., 2016).

Sehubungan dengan itu, senyawa lain seperti flavonoid diketahui dapat membentuk senyawa kompleks terhadap protein ekstraseluler yang nantinya dapat mengganggu integritas membran sel. Senyawa ini dapat menghambat pertumbuhan bakteri dengan cara merusak dinding sel, membran sel, serta dapat menonaktifkan kerja enzim pada bakteri (Cowan, 1999; Nugraha dkk., 2017).

Senyawa lain juga ditunjukkan pada senyawa terpenoid, senyawa ini diketahui dapat bereaksi dengan porin (protein transmembran) pada membran luar dinding sel bakteri dan membentuk ikatan polimer yang kuat sehingga mengakibatkan rusaknya porin. Rusaknya porin yang merupakan pintu keluar masuknya senyawa yang dibutuhkan sel bakteri akan mengurangi permeabilitas dinding sel bakteri yang mengakibatkan sel bakteri akan kekurangan nutrisi, sehingga pertumbuhan bakteri terhambat atau mati (Cowan, 1999 dalam Sukandar dkk., 2015). 
Selain senyawa alkaloid, flavonoid dan terpenoid, senyawa tanin langsung berhubungan pada metabolisme mikro organisme, melalui penghambatan fosforilasi oksidatif; mekanisme yang melibatkan kulit tanin dengan ion metabolik, mengurangi ketersediaan ion penting untuk metabolisme mikroorganisme (Xie et al., 2015) sehingga dapat menghambat dan membunuh bakteri. Selain itu senyawa tanin juga dapat membentuk ikatan kompleks dengan protein dan interaksi hidrofobik sehingga jika terbentuk ikatan hidrogen antara tanin dengan protein enzim maka kemungkinan akan terdenaturasi dan menyebabkan metabolisme bakteri terganggu (Ummah, 2010 dalam Roslizawaty dkk., 2013)

\section{KESIMPULAN DAN SARAN}

\section{Kesimpulan}

Ekstrak etanol 96\% biji kapulaga jawa memiliki aktivitas antibakteri terhadap Streptococcus pyogenes dengan rata-rata diameter daerah hambat tertinggi sebesar $12,03 \pm 0,14 \mathrm{~mm}$ pada konsentrasi $12 \%$.

Hasil uji fitokimia menunjukkan bahwa ekstrak etanol 96\% biji kapulaga jawa mengandung senyawa alkaloid, flavonoid, terpenoid dan tanin.

\section{Saran}

Perlu dilakukannya sebuah penelitian mengenai ekstrak biji kapulaga jawa (Amomum compactum Soland. ex Maton) dengan menggunakan pelarut dan mikroba uji yang lain serta penelitian lebih lanjut mengenai senyawa fitokimia pada ekstrak tersebut secara kuantitatif.

\section{UCAPAN TERIMA KASIH}

Terima kasih disampaikan kepada Laboratorium Biologi dan Laboratorium Kimia, Fakultas Matematika dan Ilmu Pengetahuan Alam, Universitas Pakuan, Bogor.

\section{DAFTAR PUSTAKA}

Agoes, A. (2010). Tanaman Obat Indonesia. Salemba Medika. Jakarta.

Aini, F., A. Djamal, dan E. Usman. (2016). Identifikasi Carrier Bakteri Streptococcus $\beta$ hemoliticus Group A pada Murid SD Negeri 13 Padang Berdasarkan Perbedaan Umur dan Jenis Kelamin. Jurnal Kesehatan Andalas. 5 (1): 145-148.

Arifianti, L., R. D. Oktarina, dan I. Kusumawati. (2014). Pengaruh Jenis Pelarut Pengekstraksi terhadap Kadar Sinensetin dalam Ekstrak Daun Orthoshipon stamineus Benth. E-Journal Planta Husada. 2 (1): 1-4.

Cowan, M. M. (1999). Plant Products as Antimicrobial Agents. Clinical Microbiology Reviews. 12 (4): 564582.

[Depkes RI] Departemen Kesehatan Republik Indonesia. (2006). Profil Kesehatan Indonesia 2004. Departemen Kesehatan RI. Jakarta.

Indijah, S. W. dan P. Fajri. (2016). Modul Bahan Ajar Cetak Farmasi: Farmakologi. Kementerian Kesehatan RI. Jakarta.

[Kemenkes RI] Kementerian Kesehatan Republik Indonesia. (2013). Panduan Praktik Klinis Bagi Dokter di Fasilitas Layanan Kesehatan Primer. Edisi I. Kementerian Kesehatan RI. Jakarta

Lee, J.A., Lee, M.Y., Seo, C.S., Jung, D.Y., Lee, N.H., Kin, J.H., Hyekyung, H.A., and Shin, H.K., (2010), AntiAshmatic Effects of an Amomum compactum Extract on an Ovalbumin (OVA)-Induced Murine Asthma Model, Biosci.Biotechnol.Biochem. 74 (9), 1814-1818.doi:10.1271/bbb.100177. https://www.tandfonline.com/doi/pdf /10.1271/bbb.100177

Milah, N., S. H. Bintari, dan D. Mustikaningtyas. (2016). Pengaruh Konsentrasi Antibakteri Propolis terhadap Pertumbuhan Bakteri 
Streptococcus pyogenes secara In Vitro. Life Science. 5 (2): 95-99.

Nugraha, A. C., A. T. Prasetya, dan S. Mursiti. (2017). Isolasi, Identifikasi, Uji Aktivitas Senyawa Flavonoid sebagai Antibakteri dari Daun Mangga. Indonesian Journal of Chemical Science. 6 (2): 91-96.

Pine, A. T. D., G. Alam, dan F. Attamimi. (2015). Standardisasi Mutu Ekstrak Daun Gedi (Abelmoschus manihot (L.) MEDIK) dan Uji Efek Antioksidan dengan Metode DPPH. Jurnal Farmasi Fakultas Kedokteran dan Ilmu Kesehatan UIN Alauddin (JF FIK UINAM). 3 (3): 111-128.

Putri, S. D. K., A. Susilowati, dan R. Setyaningsih. (2016). Uji Aktivitas Antibakteri Ekstrak Biji Kapulaga (Amomum compactum) terhadap Aeromonas hydrophyla secara In Vitro. Biofarmasi. 14 (1): 10-18.

Roslizawaty, N. Y. Ramadani, Fakhrurrazi, dan Herrialfian. (2013). Aktivitas Antibakteri Ekstrak Etanol Daun Rebusan Sarang Semut (Myrmecodia sp.) terhadap Bakteri Escherichia coli. Jurnal Medika Veterinaria. 7 (2): 91-94.

Saxena, M., J. Saxena, R. Nema, D. Singh dan A. Gupta. (2013). Phytochemistry of Medical Plants. Journal of Pharmacognosy and Phytochemistry. 1 (6): 168-182.

Setyawan, A. D., Wiryanto, Suranto, N. Bermawie dan Sudarmono. (2014).
Short Communication: Comparisons of isozyme diversity in local Java cardamom (Amomum compactum) and true cardamom (Elettaria cardamomum). Nusantara Bioscience. 6(2): 94-101.

Shulman, S. T., A. L. Bisno, H. W. Clegg, M. A. Gerber, E. L. Kaplan, G. Lee, J. M. Martin dan C. V. Beneden. (2012). Clinical Practice Guideline for the Diagnosis and Management of Group A Streptococcal Pharyngitis: 2012 Update by the Infectious Diseases Society of America. Clinical Infectious Diseases. 55 (10): 86-102.

[SNI] Standar Nasional Indonesia. (1992). SNI 01-3180-1992 Kapulaga Lokal. Standar Nasional Indonesia.

Sukandar, D., S. Hermato, E. R. Amelia dan M. Zaenudin. (2015). Aktivitas Biji Kapulaga (Amomum compactum Sol. Ex Maton). Jurnal Kimia Terapan Indonesia. 17 (2): 119-129.

Xie, Y., Yang, W., Tang, F., Chen, X., and Ren, I., (2015), Antibacterial activities of flavonoids: Structureactivity relationship and mechanism, Current Medicinal Chemistry, 22(1), 132-149.DOI: 10.2174/0929867321666140916113 443.www.eurekaselect.com/124655/ article 